\title{
Impact of Social Media Application in Business Organizations
}

\author{
R. Venkateswaran, PhD \\ Information Technology \\ Department, Salalah College of \\ Technology, Salalah, Dhofar, \\ Sultanate of Oman
}

\author{
Bernard Ugalde \\ Information Technology \\ Department, Salalah College of \\ Technology, Salalah, Dhofar, \\ Sultanate of Oman
}

\author{
Rogelio T. Gutierrez \\ Information Technology \\ Department, Salalah College of \\ Technology, Salalah, Dhofar, \\ Sultanate of Oman
}

\begin{abstract}
In the recent era of technological advancement, social media in business is slowly being appreciated by organizations globally. This is because of the fact that the internet is viewed as the new frontier for doing business. It provides a platform where organizations can get a wider audience and bypassing various difficulties like time, availability, accessibility and distance of reach. The sector is growing at a phenomenal rate.

Facebook, YouTube, Instagram, Tweeter and other social media play an essential role in how online users discover, research, and share information about brands and new product business. An online survey reported that around 60 percent of consumers who research products online, learned about a specific retailer or brand through social networking sites. Active social media users are more likely to read product reviews online to learn more about the product and to get to know the credibility, reputation and history of the company before purchase. Another essential use of social media for any business is to keep track of organizations' competitive position providing vital market information and statistics around an industry as a whole. Social media also fosters the exchange of knowledge and expertise thus speeding up innovation and development of new products based on the feedback of suggestions and recommendation of consumers. Finally, social media holds a number of real benefits for business with few negative impacts in business development. The data would be analyzed to find out the advantages and disadvantages of social media applications in business organizations.
\end{abstract}

This paper discusses the impact of social media in business organizations by highlighting the competitive advantage on organizations' engagement in social media. It aims to identify the factors why business prefers social media as marketing and communication tools over other available methods. An in-depth analysis of the advantages and disadvantages together with the risks of social media on business is further presented in the paper. Some success stories of organizations that used social media as part of their marketing campaign have been included here in this paper. This paper also attempts to figure out widely used social media applications in business. This research is qualitative in nature, which is done through literature review, observations, and interview forms mailed to business development managers.

\section{Keywords}

Business performance; e-business; social media; business marketing; innovation in business

\section{INTRODUCTION}

The internet profoundly affects how individuals communicate and build relationships today. It has been widely embraced by all kind of people of different races, cultures, and ages, in their daily lives, helping them to develop and maintain connection at a personal level and at work. These emerging technological trends are at reach making it popular and attractive to everyone, including how organizations conduct business.

The industry has shifted itself from traditional corporate communication practices to public relations utilizing social media. It is the new frontier in doing business since when social networking was put in-placed. Utilizing online networks and communities allow individuals to create and share information, ideas, interest and other forms of expression via interactive computer platforms. Most of the companies nowadays are putting equal efforts in taking advantage of using these platforms since evident advantages were noted. So what more can social media offer to business organizations?

The objective of this research is to identify the impact of social media in the point of view of business organizations. It aims to explore the advantages and disadvantages together with the risks of using social media in business organizations. Section 2 presents a short note on social media. Section 3 discusses the salient features of social media. Section 4 and 5 cites some success stories of organizations that choose to use social media campaigns, and list organizations that use social media in marketing respectively. And the rest of the paper contains literature review, summary, objectives of the study, methodology, conclusion, acknowledgments, and references.

\section{A BRIEF DISCUSSION ABOUT SOCIAL MEDIA}

Social media is the content created by users. Tim BernersLee defined it as more than a browsing medium, it is a collaboration of people who share ideas and opinion. A good example is Twitter, a free social networking micro blogging service that allows registered members to broadcast short post and follow called tweets. Facebook, Google Plus, on the other hand, allows users to post ideas, picture, videos, and will let anyone from user's friends comment, share, like post. Social media creates the potential market and an avenue to make an impression about the business thereby building credibility, brand, image, and reputation.

The number of users of social networking sites makes it attractive to marketers and organization alike to venture to social media. Facebook, for example, has about 2 billion users across the globe. An ad on such large website can reach out to a massive audience at relatively low costs making it at the forefront of business decision making.

Figure 1 presents the top social networking sites according to DreamGrow as of November 2017. Topping the list is Facebook, followed by YouTube, Instagram, and Twitter. This figure conforms to the earlier data on a number of users in each social networking sites. 


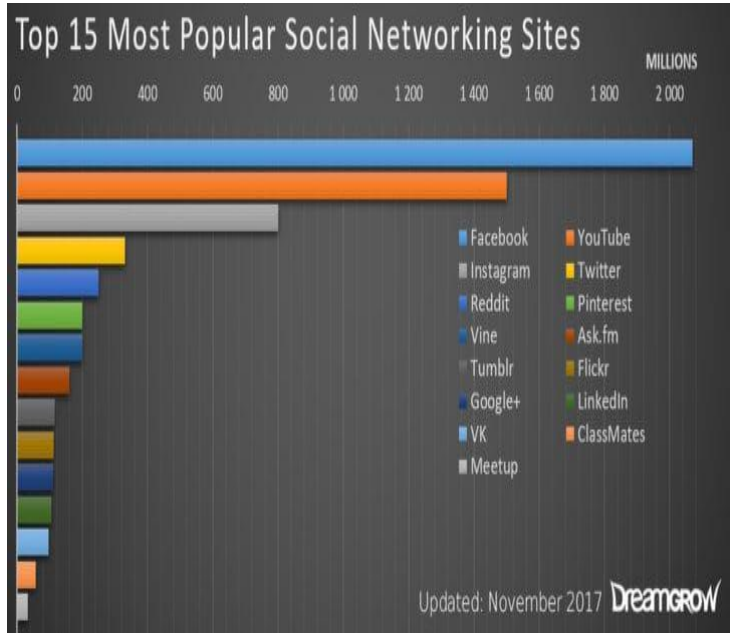

Figure 1. Most Popular Social Networking Sites

There is much to be learned about the extent to what social media can take a company. The following discussions highlight them by providing the commonly known advantages, disadvantages, and risk of engaging to social media in doing business.

\section{SALIENT FEATURES OF SOCIAL MEDIA}

A. Known Advantages of Social Media

Table 1 presents the advantages of social media based on the point of view of business organizations based on several features as follows:

Table 1. Advantages of Social Media

\begin{tabular}{|c|c|}
\hline Features & Advantages \\
\hline $\begin{array}{l}\text { Learn about the } \\
\text { audience }\end{array}$ & $\begin{array}{l}\text { Keep up-to-date with what people are } \\
\text { doing and what is happening in their } \\
\text { lives }\end{array}$ \\
\hline $\begin{array}{l}\text { Target audiences } \\
\text { more effectively }\end{array}$ & $\begin{array}{l}\text { Connections are usually made with } \\
\text { others who share same interests }\end{array}$ \\
\hline Cost is lower & $\begin{array}{l}\text { Lower cost compared to newspaper, } \\
\text { magazines, radio and TV. }\end{array}$ \\
\hline $\begin{array}{l}\text { Receive instant } \\
\text { feedback from } \\
\text { consumers' } \\
\text { perspective }\end{array}$ & $\begin{array}{l}\text { Quick, honest, and detailed feedback } \\
\text { from the consumers }\end{array}$ \\
\hline $\begin{array}{l}\text { Personalizes } \\
\text { engagement with } \\
\text { consumers }\end{array}$ & $\begin{array}{c}\text { Allows deeper engagements with } \\
\text { consumers and personalized customer } \\
\text { service }\end{array}$ \\
\hline $\begin{array}{l}\text { Creates corporate } \\
\text { identity }\end{array}$ & $\begin{array}{c}\text { Builds organizations' credibility, brand, } \\
\text { image, and reputation. Creating and } \\
\text { presenting business organizations' } \\
\text { identity. }\end{array}$ \\
\hline $\begin{array}{l}\text { Improve market } \\
\text { intelligence }\end{array}$ & $\begin{array}{c}\text { Keep track of organizations' competitive } \\
\text { position providing vital market } \\
\text { information and statistics around an } \\
\text { industry as a whole }\end{array}$ \\
\hline $\begin{array}{l}\text { Speeds up } \\
\text { innovation and } \\
\text { development of } \\
\text { new products }\end{array}$ & $\begin{array}{l}\text { Fosters exchange of knowledge and } \\
\text { expertise thus speeding up innovation } \\
\text { and development of new products based } \\
\text { on the feedback of suggestions and }\end{array}$ \\
\hline
\end{tabular}

\begin{tabular}{|c|c|}
\hline $\begin{array}{c}\text { visibility in the } \\
\text { internet }\end{array}$ & $\begin{array}{c}\text { recommendation of consumers. } \\
\text { Increanke website traffic and search } \\
\text { ranking }\end{array}$ \\
\hline $\begin{array}{c}\text { Facilitate hiring } \\
\text { and recruitment }\end{array}$ & $\begin{array}{c}\text { Effectively can be used to recruit new } \\
\text { talent. }\end{array}$ \\
\hline $\begin{array}{c}\text { Easier and faster } \\
\text { communication }\end{array}$ & $\begin{array}{c}\text { Improves communication between } \\
\text { business organizations and consumers }\end{array}$ \\
\hline $\begin{array}{c}\text { Creating trust } \\
\text { and loyalty }\end{array}$ & Generating consumer trust and loyalty \\
\hline
\end{tabular}

\section{B. Known Disadvantages and Risks of Social Media}

Leveraging social media in business also post some disadvantages and risks. The tables below summarizes each factor:

Table 2. Disadvantages of Social Media

\begin{tabular}{|c|c|}
\hline SN & Disadvantages of Digital Marketing in Social Media \\
\hline 1 & Updating social media accounts takes time and effort. \\
\hline 2 & Social media is not completely free. \\
\hline 3 & $\begin{array}{c}\text { Information is only visible for a short time before } \\
\text { newer posts replace it. }\end{array}$ \\
\hline 4 & Reduce face to face communication \\
\hline 5 & Social media marketing makes you lose control \\
\hline
\end{tabular}

Table 3. Risk of Social Media

\begin{tabular}{|c|c|}
\hline SN & Risks of Digital Marketing in Social Media \\
\hline 1 & Negative comments \\
\hline 2 & Viruses and malware \\
\hline 3 & Brand hijacking \\
\hline 4 & Lack of control over corporate content \\
\hline 5 & Unrealistic customer expectations \\
\hline 6 & Non-compliance with record management regulations \\
\hline
\end{tabular}

Tables 1,2 and 3 portraits the salient features of social media. Even though there are many of positive factors to influence social media in business, organizations still need to look into some of the disadvantages and risks for efficiency. Now, the next question is how are organizations integrate social media into their business? The following section illustrates how organizations effectively and creatively used social media in their businesses.

\section{SUCCESS STORIES IN SOCIAL MEDIA}

Below presents three business organizations that leverage social media in doing their business successfully. Examples of their campaigns along with some takeaways are provided so anyone can benchmark to include in business efforts.e're starting to see more and more big brands bring social media to "real life" by creating viral stunts like this one. 
Case 1 Pepsi created a vending machine that gives away a free can of Pepsi in return for a "like" on their fan page. You could either sync your phone with the machine or log in to Facebook on the touchscreen of the machine if you didn't have a smartphone.

While this isn't necessarily a cost-effective strategy, they were able to track exactly who received the free samples, as opposed to handing them out at random.

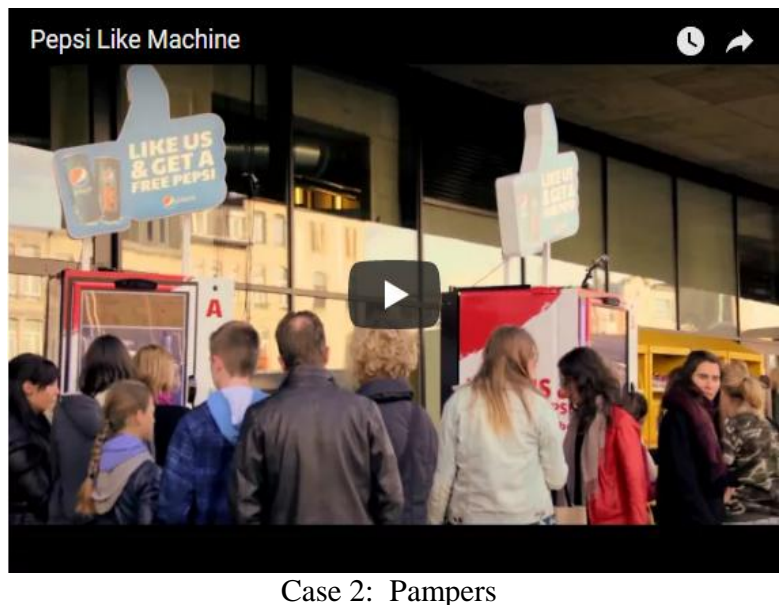

Nothing is quite as adorable and coo-worthy as babies, so you might think that Pampers has it pretty easy when it comes to marketing on social media. However, their particular product is less than glamorous for the families that use them.

So, Pampers has chosen to ignore the fact that diaper changes are the least anticipated moment of being a parent. They instead focus on the part that is compelling: the undeniable emotion and love behind holding and caring for your newborn.

In their social media campaigns, they focus on bringing out the special bond between a parent and a child. This bond tugs at heartstrings much harder than any poop joke or diaper feature ever could. They contribute emotional appeal to the social media world instead of adding to the noise with overtly sales-y messages.

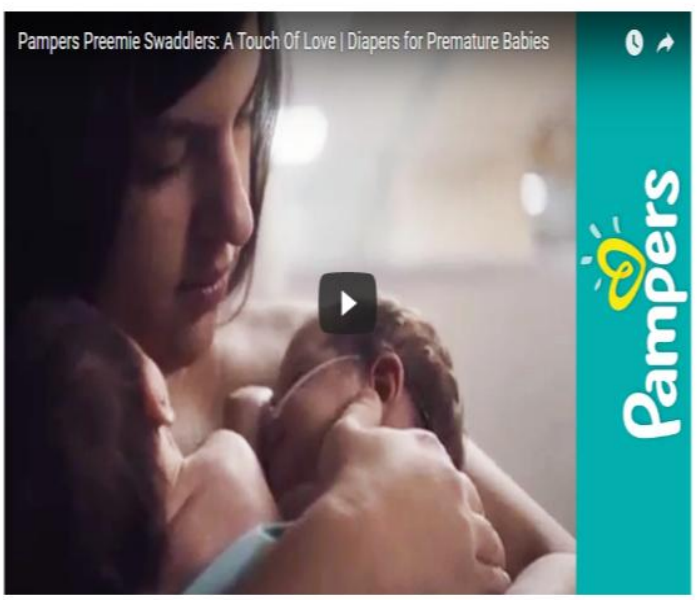

Case 3: JetBlue Airways

Competition in the airline industry is very though and customer service continues to be of the most important element in airline's success. Airline can quickly go off the grid if frustration arises. Thus airline companies value so much customer experience and satisfaction so be considered as leading air transport carrier in the industry.

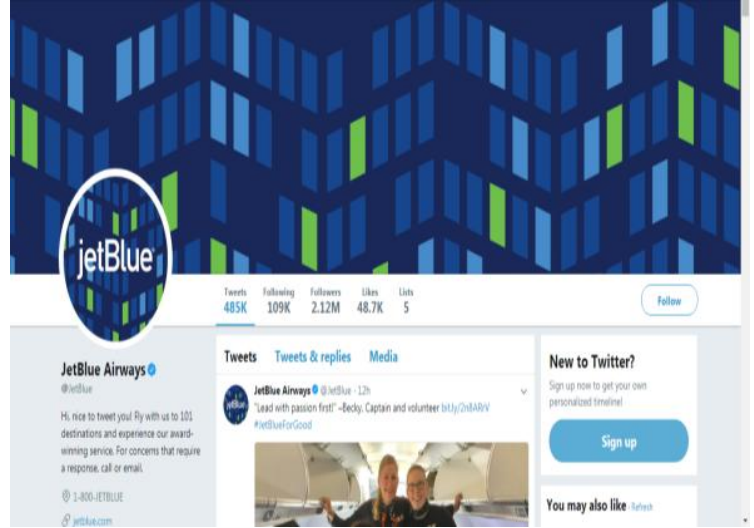

Figure 4. JetBlue Tweeter Account

According to Social Bakers, JetBlue's impressive 71\% response rate on Twitter is almost as impressive as the account's average response time of 9 minutes - according to that same report from Social Bakers. That means users are almost immediately being guided through the sometimes tumultuous process of air travel, without even having to sit through those awful recordings.

So whatever your strategy may be for social media, consider this: it's not always about who posts the most, or what you're giving away. It's about the impression that you're giving your audience - and how that either promotes the identity of your brand, or reminds customers that you're still just as far behind the times.

\section{OTHER GIANT BUSINESS FIRMS WHO USED SOCIAL MEDIA FOR BUSINESS}

Table 4 lists the giant firms who deploy social media tools for their business, which proves that social media in business is growing tremendously.

Table 4. Giant Business Firms Who used Social Media for Business

\begin{tabular}{|c|c|c|c|}
\hline Nike & Oreo & Samsung & Sony \\
\hline Ford & Doritos & Pizza Hut & Cree \\
\hline Zappos & Nestle & Doce & Jelly Belly \\
\hline Cadbury & Godiva & Amazon & Apple \\
\hline Microsoft & McDonals & Clairol & Coke \\
\hline
\end{tabular}

Having said all these things, let us turn back past studies about social media in business with the objective of unfolding the factors affecting organization to use this medium in business organizations.

\section{REVIEW OF LITERATURE}

Many studies from literature reveal that social media used for business developments. Social media marketing, strategies, and its impact [1] studies emphasized about social media which helps in connecting themselves with social networking sites through which now people can stay far and yet remain connected. Apart from this media like Facebook create a loyal connection between product and individual which leads 
to large advertising opportunities. Similarly, other social media like Blogs create a platform to post a comment on any event which needs to be publicized also can be utilized as a promotional technique for customer's adoption as well as for promotions. Another research "the History of Social Media and its impact on business" studies.

[2] say that social networking has become daily practice in some users' lives. In this article, the authors describe features and the evolution of social media, including major social networking sites that came into existence during the 21st century. The research work of doctoral student [3] from USA studies reported that the management of the company has to develop the relevant organizational capabilities so as to ensure that the social media integration process is effective, and the core function such as marking, advertising, public relations and customers serves can be enhanced. The corporate entities present in the current business environment have to ensure that they integrate the social media tools. The research studies of students from New York University

[4] found that promotional events combined with features enabling implicit or explicit advocacy on social media platforms result in statistically significant positive abnormal returns, in terms of new followers for the corresponding brands. A researcher from India [5] observed that Majority of the companies are using a combination of traditional and social media to reach out to their customers. It has been seen that use of social media has helped companies to reach out to more customers and to satisfy their needs better. Companies have seen an enhancement in their brand awareness and brand image by use of social media. Researcher from Malaysia titled

"Impact of Social Media Usage of Organization" [6] observed through the interviews conducted from top companies and reported that in order to identify the factors that influence the social media usage and its impact on organizations, the qualitative method was used. Six organizations were selected from the 36 organization that are using social media effectively. Semi-structured face-face interviews were conducted. A general interview guide was used where the topics and issues are specified in advance, in outline form; the sequence and wording of questions were altered during the course of the interview. On average, interviews lasted approximately an hour and were recorded and later transcribed. In most companies, the social media comes from either marketing or corporate communication department, except one organization which had its own social media department. For two companies, the Senior Manager along with the Social Media Executive was interviewed. For the others, the senior managers were interviewed. The data collection took place from October 2011 to February 2012. The organizations interviewed are from five different industries i.e. Consumer products, Telecommunication, Airlines, Manufacturing, and Finance.

Table 5. Factors Identified through Interview

\begin{tabular}{|l|l|}
\hline Themes & Factors \\
\hline $\begin{array}{l}\text { Purpose of Social } \\
\text { Media usage }\end{array}$ & $\begin{array}{l}\text { Branding, advertising and promotion. } \\
\text { Information search about competitors } \\
\text { and customers Building customer } \\
\text { relationship, Customer service }\end{array}$ \\
\hline $\begin{array}{l}\text { Factors influence } \\
\text { Social Media } \\
\text { usage }\end{array}$ & $\begin{array}{l}\text { Top management support relative } \\
\text { advantage, } \\
\text { compatibility, entrepreneurial }\end{array}$ \\
\hline
\end{tabular}

\begin{tabular}{|l|l|}
\hline & \multicolumn{1}{|c|}{ orientation and institutional } \\
\hline $\begin{array}{l}\text { Social Media on } \\
\text { organization }\end{array}$ & $\begin{array}{l}\text { Enhance customer service, } \\
\text { relationship building, cost } \\
\text { reduction (marketing, communication, } \\
\text { Customer service). Improved brand } \\
\text { visibility, image and competitive } \\
\text { company ime } \\
\text { position }\end{array}$ \\
\hline
\end{tabular}

Table 5 shows that factors identified in terms of social media usage, the influence of social media usage and impact on the organization [6].

\section{OBJECTIVES OF THE STUDY}

The main objective of the study is to pinpoint the factors that influence organizations to select social media for business, particularly:

1. Identify the factors that play major role in the selection of social media in business development.

2. Outline the advantages, disadvantages, and risks social media in business.

3. Examine how organizations successfully integrated social media into business.

4. Identify organizations who leverage social media in business.

\section{METHODOLOGY}

This research is a descriptive study using a qualitative method with the support of literature reviews available from various sources, secondary data from observations in online social media applications and tools, and interview forms mailed to business development managers.

\section{SUMMARY}

Past studies reveal that certain factors are influencing organizations in selecting social media for business. The factors have been highlighted below:

Table 6. Factors Emphasized in Review of Literature

\begin{tabular}{|l|l|}
\hline $\begin{array}{l}\text { Author } \\
\text { Reference } \\
\text { Number }\end{array}$ & Factors Emphasized in Review of Literature \\
\hline$[1]$ & $\begin{array}{l}1 . \\
2 .\end{array} \quad$ Large advertising opportunities \\
user & $\begin{array}{l}3 . \quad \text { Companies have interaction with } \\
\text { consumers directly online }\end{array}$ \\
\hline$[2]$ & $\begin{array}{l}1 . \quad \text { Transformed the interaction and } \\
\text { communication of individuals throughout the } \\
\text { world. } \\
\text { 2. } \quad \text { Use of social media website has } \\
\text { increased the channel of communication and its } \\
\text { effectiveness in the organization. } \\
\text { 3. Professional gains as these social } \\
\text { media will enable collaborating without leaders } \\
\text { in their respective industries }\end{array}$ \\
\hline
\end{tabular}




\begin{tabular}{|c|c|}
\hline [3] & $\begin{array}{l}\text { 1. Consumers have now shifted to } \\
\text { online social community } \\
\text { 2. Company have opportunity to interact } \\
\text { with the customers. } \\
\text { 3. Advertising, public relation and } \\
\text { customer services can be enhanced. }\end{array}$ \\
\hline [4] & $\begin{array}{l}\text { 1. Social commerce that examined the } \\
\text { consumer behavior } \\
2 \text {. Impact of social media promotional } \\
\text { events on consumer's perception of } \\
\text { participating brand. } \\
\text { 3. } \quad \text { More effective for brands that already } \\
\text { have large user base. }\end{array}$ \\
\hline [5] & $\begin{array}{l}\text { 1. Majority of the companies are using } \\
\text { social media to reach out to their customers. } \\
\text { 2. Enhancement in their brand } \\
\text { awareness and brand image by use of social } \\
\text { media } \\
\text { 3. } \quad \text { Gold mine for brand building }\end{array}$ \\
\hline [6] & $\begin{array}{l}\text { 1. Social media comes under either } \\
\text { marketing or corporate communication } \\
\text { department. } \\
2 . \quad \text { Social media are used by business } \\
\text { firms and governmental organizations as a } \\
\text { communication tool. } \\
3 \text { Social media has been recognized as } \\
\text { the most powerful medium in business practice. }\end{array}$ \\
\hline [7] & $\begin{array}{l}\text { 1. Industry shift from traditional } \\
\text { corporate communications practices to public } \\
\text { relation utilizing social media. } \\
\text { 2. Social medial is going to continue to } \\
\text { develop and change corporate communication } \\
\text { practices. } \\
3 \text { C Creates opportunities for meaningful } \\
\text { conversations, successful campaigns and } \\
\text { realizing industry ideals. }\end{array}$ \\
\hline [8] & $\begin{array}{l}\text { 1. Social media growth in a fast } \\
\text { changing environmental and technological } \\
\text { environment. } \\
\text { 2. Recruitment/Communication officers } \\
\text { must approach social media in a proactive way. } \\
\text { 3. Smartphone as the primary device } \\
\text { they rely on to stay connected with family and } \\
\text { friends. and stay informed to current events and } \\
\text { news. }\end{array}$ \\
\hline
\end{tabular}

It was also noted leveraging social media in business brings competitive advantage to organizations. However, organizations needs also to look into the disadvantages and risk that social media might bring.

Some known organizations have already successfully ventured on using social media part of their marketing campaign and more and more organizations are gearing towards the same direction.

\section{CONCLUSION}

This tiny study addresses the factors and prime factors, advantages and disadvantages of Social Media that influence business people to select Social Media in their business development and performance. Due to time constraints, interview mail forms are not yet completed but through observation and detailed literature survey reveals that most of the companies are using a combination of traditional and social media to find out to their customers. It has been seen that use of social media application and tools has helped companies to make more branding of their products and reach their brands to more customers and to satisfy their needs better. Companies have seen an enhancement in their brand awareness and brand image by use of social media There are many advantages but few disadvantages based on these studies but Companies can use the social media better by making their message clear, avoiding chaos and ensuring that their online image matches with their brand image. Marketers consider social media, a space many of their consumers, as a gold mine for brand and business development and building.

\section{ACKNOWLEDGEMENT}

The author wishes to would like to acknowledge Salalah College of Technology for its continuing support of this work. Also, the researcher would also like to acknowledge the support of $2^{\text {nd }}$ and $3^{\text {rd }}$ authors for guiding author in finishing the paper.

\section{REFERENCES}

[1] Vivek Bajpai et(2012), SOCIAL MEDIA MARKETING: STRATEGIES \& ITS IMPACT, International Journal of Social Science \& Interdisciplinary Research, India,Vol.1 Issue 7, ISSN 2277 3630. pp 214-223.

[2] Simeon Edosomwan et (2011), The History of Social Media and its Impact on Business, The Journal of Applied Management and Entrepreneurship, 2011, Vol. 16, No.3.pp 119-205.

[3] Mohammad Yousef Abuhashesh(2014), Integration of Social Media in Businesses,International Journal of Business and Social Science, USA, Vol. 5, No. 8; July 2014,pp 202-209.

[4] Panagiotis Adamopoulos(2014), The Effectiveness of Promotional Events in Social Media, Department of Information operations and Management Sciences, New York University research paper, Workshop on information systems and economics, USA.

[5] Sandeep Bhanot(2014), A STUDY ON IMPACT OF SOCIAL MEDIA ON COMPANY PERFORMANCE, research paper, India

[6] Parveen, Farzana (2012), "Impact Of Social Media Usage On Organizations", PACIS 2012 Proceedings. Paper 192.

[7] Laura Matthews (2010), Social Media and the Evolution of Corporate Communications, The Elon Journal of Undergraduate Research in Communications, USA, Vol. 1, No. 1 • Winter 2010, pp 17-23.

[8] Lisette de Vries(2012), Impact of Social Media on Consumers and Firms, University of Groningen, Groningen, The Netherlands ,Printing: Ipskamp Drukkers, Enschede ,ISBN: 978-90-367-7243-3 ,ISBN 
(e-book): 978-90-367-7244-0.

[9] Natascha Zeitel-Bank(2014), SOCIAL MEDIA AND ITS EFFECTS ON INDIVIDUALS AND SOCIAL SYSTEMS , International Conference, 25-27, June, Slovenia, pp 1183- 1190.

[10] James Barnes et(2013), The Economic Impact of Social Media on Small Businesses, Agricultural Economics Association Annual Meeting, February 1-4, 2013, Dallas, TX, pp 1-25

[11] Lindsay Kolowich(2016), how to use facebook for business : 13 essential tips for business, April 18, 2016, Web site : http://blog.hubspot.com/marketing/facebookfor-business-tips.

[12] Nate Kieven , author, Linked Stregeties , reason why you should make your company page on linkedIn social mediaWebsithttp://www.linkedstrategies.com/reasonswhy-you-should-make-your-company-page-on-linkedin

[13] Mark Scott (2013) author, With a little help from Social Media: Top 10 Business Success stories, November issue,websitehttp://www.socialmediatoday.com/content/ little-help-social-media-top-10-business-success-stories/ 